\title{
Chapter

\section{Effect of untreated wastewater on soil quality: A case study in Ranipur Rao watershed in Haridwar region (Uttarakhand), India}

\author{
Manisha Bharti, Nitin Kamboj ${ }^{*}$ and Vishal Kamboj \\ Department of Zoology and Environmental Science, Gurukula Kangri (Deemed to be University), \\ Haridwar 249404, Uttarakhand, India
}

Abstract

The current study seeks to assess the sustainability of soil by identifying the effect of wastewater on soil nutrient quality by using the nutrient index approach in different land uses in Ranipur Rao Watershed in the Haridwar region of Uttarakhand state. The vast majority of the wastewater produced in urban areas is treated proceeding to irrigation, while in low-income nations wastewater treatment is not important. Clean water irrigated soil samples from forest area were taken as control. Wastewater irrigated soil samples were taken from industrial and agricultural areas. Soil organic carbon (\%) of soil ranged from $0.70-0.84$ at clean water irrigated sites in the forest area. Whereas, $0.48-0.75$ at wastewater irrigated sites in the industrial area and 0.53-0.79 at wastewater irrigated sites in the agricultural area. The content of available nitrogen in soil of agricultural wastewater irrigated area indicates high status as compared to industrial and forest areas. The circumstance consequently requests the selection of fitting administration rehearses to support the fruitfulness status in study territory. These practices may include such practices as site-specific nutrient management, increased use of organic nutrient sources, sustainable land use and cropping systems, and appropriate agronomic practices.

\section{Keywords}

Land use, Nutrient index, Soil fertility, Wastewater, Watershed management 
Abbreviations: \%: Percent, GPS: Geographical Positioning System, pH: Potential of Hydrogen, EC: Electrical Conductivity, cm: Centimeter, $\mathrm{mm}$ : Millimeter, AN: Available Nitrogen, AP: Available Phosphorus, AK: Available Potassium, AS: Available Sulphate, Ca: Calcium, Mg: Magnesium, Zn: Zinc, Cu: Copper, Fe: Iron, Mn: Manganese, SNI: Soil Nutrient Index, dS/m: DeciSiemens per metre; meq/100g: Milliequivalent/100gram; SD: Standard Deviation, gm: Gram.

\section{Introduction}

The population in the world is currently growing at a rate of around 1.05\% per year (down from 1.08\% in $2019,1.10 \%$ in 2018 , and $1.12 \%$ in 2017). The current average population increase is estimated at 81 million people per year (Tilley et al., 2014). In developing countries, the increasing requirement for freshwater in agricultural production is not limited to, But needs per person and also supplies the needed irrigate resources industry needs and priorities of the urban communities in these areas (Mohson and Ali, 2017). The discharge of raw sewage in the environment, contaminating the quality of surface and groundwater streamflow (Abedikoopayee et al., 2003; Karimzadeh et al., 2012). So, the use of treated wastewater in agricultural areas decreases the use of water, which in addition to other practices, such as household works like bathing, washing, and maybe drinking (Alikhales and Smalzadeh, 2010; Kumar et al., 2018).

The vast majority of the wastewater produced in urban areas is treated proceeding to irrigation, while in low-income nations wastewater treatment is not important. Thus the combination of treated, partially treated, and untreated wastewater is commonly used for agricultural purposes (Hussain et al., 2002). The World Health Organization estimates that nearly 20 million hectares throughout the world are irrigated using untreated wastewater (WHO, 1989).

In wastewater, the occurrence of organic, inorganic, and microbial contaminants is an earlier stage of depuration is necessary before reuse in irrigation. To evade the contamination of soil, crops, and adjacent water resources and accordingly the dispersion of waterborne diseases or the degradation of soil. The extent to which wastewater has to be treated before irrigation depends on the limitations established in local or international water quality criteria for irrigation (Kretschmer et al., 2002). Soil, the source of life, is the most essential and valuable natural resource which is not renewable quickly. Soil quality is a measure of the form of soil components with the necessities of at least one biotic species as well as to human need or use (Johnson et al., 1997). Soil fertility is a dynamic natural property that can alter through the impact of natural and human-derived factors (Kavitha and Sujhata, 2015). Changes in soil properties in different land use maybe because of dynamic collaborations among ecological factors like weather, parent material, geography, and land use, and land cover (Bharti and Kamboj, 2018). The fertility of the soil is determined by the presence or absence of nutrients which have 
agronomic importance (Lone et al., 2016). Soil nutrient composition plays a key role in determining the goodness of the soil. Healthy soil will have all the essential elements in the right proportions to support healthy plant growth throughout its life cycle (Art Efretuei, 2016). Degradation of soil quality has posed a threat to agricultural productivity, economic growth, and a healthy environment on a global scale (Eswaran et al., 2001). Different types of wastewater use in different land-use irrigation that also affect the biodiversity of soil (Bharti and Kamboj, 2020).

Maintaining soil health and sustainable agricultural production, replenishment of macro and micronutrients, and addition of soil amendments is a must in the soil to obtain good crop yields. If their status in the soil is known before the crop is sown, it provides a sound basis for determining the nutrient requirements for the desired production (Amara et al., 2016). The extent of the beneficial impacts depends on the local conditions of the specific project. The fundamental negative part of reusing treated and untreated wastewater in agricultural areas is the contamination of soil systems, the likely defilement of yields and water resources, and the intrinsic risk of harmful impacts that pollution stances to the unprotected living beings (Juan et al., 2014). Nowadays, under freshwater scant conditions, it becomes almost obligatory for farmers to consider and use any sources of water, especially in many regions (Kumar et al., 2020).

So, Adoption of appropriate land use management practices and land use planning would help to minimize the degradation in soil physical quality and would ensure sustainable crop production and productivity (Ramesh et al., 2008). Therefore, this investigation was made to study the effect of wastewater on the soil in different land use in district Haridwar (Uttarakhand). The nutrient index was calculated to show the level of contamination in soils at wastewater-irrigated different land-use sites.

\section{Study area}

The present study was carried out in three different land-use types i.e. forest area, industrial area, and an agricultural area in Ranipur Rao seasonal hill river watershed area in the Haridwar region (Uttarakhand). The selection of the study area was based on their land-use patterns and type of irrigation in the land.

\section{Sample collection, preparation, and preservation}

The soil samples were collected from 0-15 and 15-30 cm. depth with the help of an auger from March 2017 to February 2018, using the GPS locations in 3 different areas. Composite soil sampling was done inside each land-use area and mixed thoroughly following a standard method for sample preparation (Andreas and Berndt, 2005). All the collected soil samples were air-dried after analyzed $\mathrm{pH}$ and EC and then soil samples were dried in shade, crushed with motor and pestle, and then sieved through a 2.0 $\mathrm{mm}$ sieve. The dried soil samples were stored for further analysis of the physical, chemical, and nutrient characteristics of soil samples. 


\section{Physico-chemical and nutrient analysis of soil}

A total of 13 physico-chemical and nutrient characteristics, $\mathrm{pH}$, electrical conductivity, organic carbon, available nitrogen, available phosphorus, available potassium, available calcium, available magnesium, available sulphate, available zinc, available iron, available manganese, and available copper were analyzed in the laboratory, following the standard methods (Jackson, 1958; Trivedy and Goal, 1998; Anderson and Ingram, 1993; Behera, 2014).

\section{Soil nutrient index determination:}

To evaluate the fertility status of soils in the study area, different soil physico-chemical characteristics that affect nutrient availability including $\mathrm{pH}$, electrical conductivity, available $\mathrm{N}, \mathrm{P}, \mathrm{K}$ and $\mathrm{S}$, exchangeable $\mathrm{Ca}$ and $\mathrm{Mg}$, and available micronutrients ( $\mathrm{Zn}, \mathrm{Cu}, \mathrm{Fe}$, and $\mathrm{Mn}$ ) were calculated based on the specific rating chart (Table 1) modified from Brajendra et al. (2014). Soil nutrient index (SNI) was worked out to depict the available status of each macronutrient at a series level by using the formula proposed by Parker's et al. (1951):

$$
\mathrm{SNI}=\frac{(\mathrm{Nl} \times 1)+\mathrm{Nm} \times 2+\mathrm{Nh} \times 3}{2 \mathrm{Nt}}
$$

Table 1. Rating chart for soil test values and their nutrient indices.

\begin{tabular}{|c|c|c|c|c|}
\hline Soil property & Unit & Range & & \\
\hline Soil pH & $\mathrm{pH}$ unit & $<6.0$ (Acidic) & 6.1-8.0 (Neutral) & $>8.0$ (Alkaline) \\
\hline Electrical conductivity & $\mathrm{dS} / \mathrm{m}$ & $<1.0$ (Normal) & 1.0-2.0 (Critical) & $>2.0$ (Injurious) \\
\hline Organic Carbon & $\%$ & $<0.5$ (Low) & 0.5-0.75 (Medium) & $>0.75$ (High) \\
\hline Available Nitrogen (N) & $\mathrm{kg} / \mathrm{ha}$ & $<280$ (Low) & 280-560 (Medium) & $>560$ (High) \\
\hline $\begin{array}{l}\text { Available Phosphorus } \\
\left(\mathrm{P}_{2} \mathrm{O}_{5}\right)\end{array}$ & $\mathrm{kg} / \mathrm{ha}$ & $<10$ (Low) & 10-25 (Medium) & >25 (High) \\
\hline Available Potassium $\left(\mathrm{K}_{2} \mathrm{O}\right)$ & $\mathrm{kg} / \mathrm{ha}$ & $<110$ (Low) & 110-280 (Medium) & $>280$ (High) \\
\hline Available Sulphur (S) & Ppm & $<10$ (Low) & 10-30 (Medium) & >30 (High) \\
\hline Exchangeable Calcium (Ca) & meq $/ 100 \mathrm{~g}$ & $<1.5$ (Low) & 1.5-4.5 (Medium) & $>4.5$ (High) \\
\hline Exchangeable Mg & $\mathrm{meq} / 100 \mathrm{~g}$ & $<1.5$ (Low) & 1.5-4.5 (Medium) & $>4.5$ (High) \\
\hline Available Zinc (Zn) & Ppm & $<0.6$ (Low) & 0.6-1.0 (Medium) & >1.0 (High) \\
\hline Available Manganese (Mn) & Ppm & $<0.07$ (Low) & 0.07-0.2 (Medium) & $>0.2$ (High) \\
\hline Available Iron (Fe) & ppm & $<4.5$ (Low) & 4.5-5.5 (Medium) & $>5.5$ (High) \\
\hline Available Copper (Cu) & ppm & $<0.07$ (Low) & 0.07-0.2 (Medium) & $>0.2$ (High) \\
\hline Nutrient Index & Index & I & II & III \\
\hline
\end{tabular}


Table 2. Nutrient index with range and remarks.

\begin{tabular}{lll}
\hline Nutrient Index & Range & Remarks \\
\hline I & Below 1.67 & Low \\
II & $1.67-2.33$ & Medium \\
III & Above 2.33 & High \\
\hline
\end{tabular}

Where, $\mathrm{Nt}=$ total number of samples analyzed for a nutrient in any given area; $\mathrm{Nl}=$ number of samples falling in the low category of nutrient status ; $\mathrm{Nm}=$ number of samples falling in the medium category of nutrient status; $\mathrm{Nh}=$ number of samples falling in the high category of nutrient status ; An SNI value less than 1.67 , between 1.67 to 2.33 , and more than 2.33 indicates low, medium, and high fertility status of soil, respectively (Table 2).

Soil nutrient index of three different land-use areas was evaluated regarding $\mathrm{pH}$, Organic Carbon, primary and secondary nutrients, and micronutrients, for example, $\mathrm{Fe}, \mathrm{Zn}, \mathrm{Cu}$, and $\mathrm{Mn}$. The results obtained are presented in Tables 3-6, and discussed in the following headings.

\section{Effect of wastewater on soil $\mathrm{pH}$}

During the study year (2017-2018), soil from clean water-irrigated sites, i.e., forest area, showed $\mathrm{pH}$ values ranged from 5.78-6.76, whereas in wastewater irrigated sites i.e. industrial and agricultural area soil $\mathrm{pH}$ ranged from 5.72-6.90 and 7.0-7.67 (Table 3). Wastewater is a source of acidic constituents and diminishes the soil $\mathrm{pH}$ because of the decay of organic matter and materialization of organic acids containing elements in the soil system. (Vaseghi et al., 2005; Khai et al., 2008). The Forest area also showed slightly acidic $\mathrm{pH}$ because of the decomposition of plant litter residues. This indicates a low status of $\mathrm{pH}$ in the forest and industrial area and medium status in an agricultural area (Table 6). The fertility rating of the $\mathrm{pH}$ of agriculture was medium due to the continuous application of different types of fertilizers.

\section{Effect of wastewater on soil electrical conductivity}

Electrical conductivity $(\mathrm{dS} / \mathrm{m})$ of soil ranged from 0.36-0.85 at clean water irrigated sites in the forest area. Electrical conductivity ranged from 0.51-0.65 at wastewater irrigated sites in the industrial area and 0.64-0.89 at wastewater irrigated sites in an agricultural area (Table 3). The soil nutrient index of electrical conductivity indicates the medium status in all land use areas.

\section{Effect of wastewater on soil organic carbon}

Soil organic carbon (\%) of soil ranged from 0.70-0.84 at clean water irrigated sites in the forest area. Whereas, 0.48-0.75 at wastewater irrigated sites in an industrial area and 0.53-0.79 at wastewater irrigated sites in an agricultural area (Table 3). This indicates the medium status of soil organic carbon 
Table 3. Descriptive status of measured soil properties in Ranipur Rao watershed.

\begin{tabular}{|c|c|c|c|c|c|}
\hline \multicolumn{6}{|l|}{ Soil reaction $(\mathrm{pH})$} \\
\hline \multirow[b]{2}{*}{ Land use areas } & \multicolumn{5}{|c|}{ Percent of samples falling within range } \\
\hline & $\begin{array}{l}<6.0 \\
\text { (Acidic) }\end{array}$ & $\begin{array}{l}6.0-8.0 \\
\text { (Neutral) }\end{array}$ & $>8.0$ (Alkaline) & Range & Mean \pm SD \\
\hline Forest area & 16.7 & 83.33 & 0 & $5.78-6.76$ & $6.3 \pm 0.33$ \\
\hline Industrial area & 33.33 & 66.66 & 0 & $5.72-6.90$ & $6.27 \pm 0.48$ \\
\hline Agricultural area & 0 & 100.0 & 0 & 7.0-7.67 & $7.25 \pm 0.26$ \\
\hline \multicolumn{6}{|c|}{ Electrical conductivity } \\
\hline Land use areas & $\begin{array}{l}<1.0 \mathrm{dS} / \mathrm{m} \\
\text { (Normal) }\end{array}$ & $\begin{array}{l}1.0-2.0 \mathrm{dS} / \mathrm{m} \\
\text { (Medium) }\end{array}$ & $>2.0 \mathrm{dS} / \mathrm{m}$ (High) & Range & Mean \pm SD \\
\hline Forest area & 100 & 0 & 0 & $0.36-0.85$ & $0.60 \pm 0.19$ \\
\hline Industrial area & 100 & 0 & 0 & $0.51-0.65$ & $0.57 \pm 0.05$ \\
\hline Agricultural area & 100 & 0 & 0 & $0.64-0.89$ & $0.74 \pm 0.08$ \\
\hline \multicolumn{6}{|l|}{ Organic carbon } \\
\hline Land use areas & $<0.5 \%$ (Low) & $\begin{array}{l}0.5-0.75 \% \\
\text { (Medium) }\end{array}$ & $>0.75 \%$ (High) & Range & Mean \pm SD \\
\hline Forest area & 0 & 66.66 & 33.33 & $0.70-0.84$ & $0.74 \pm 0.05$ \\
\hline Industrial area & 16.7 & 83.33 & 0 & $0.48-0.75$ & $0.60 \pm 0.10$ \\
\hline Agricultural area & 0 & 83.33 & 16.7 & $0.53-0.79$ & $0.65 \pm 0.10$ \\
\hline \multicolumn{6}{|l|}{ Exchangeable Ca } \\
\hline Land use areas & $\begin{array}{l}<1.5 \\
\text { meq/100g } \\
\quad(\text { Low })\end{array}$ & $\begin{array}{l}1.5-4.5 \\
\mathrm{meq} / 100 \mathrm{~g} \\
\text { (Medium) }\end{array}$ & $\begin{array}{l}>4.5 \mathrm{meq} / 100 \mathrm{~g} \\
\text { (High) }\end{array}$ & Range & Mean \pm SD \\
\hline Forest area & 0 & 100 & 0 & $2.65-3.35$ & $2.99 \pm 0.29$ \\
\hline Industrial area & 0 & 16.7 & 83.33 & $3.77-6.80$ & $4.88 \pm 1.04$ \\
\hline Agricultural area & 0 & 83.33 & 16.7 & $3.90-4.65$ & $4.25 \pm 0.27$ \\
\hline \multicolumn{6}{|l|}{ Exchangeable Mg } \\
\hline Land use areas & $\begin{array}{l}<1.5 \\
\text { meq/100g) }\end{array}$ & $\begin{array}{l}\text { 1.5-4.5 } \\
\text { meq/100g } \\
\text { (Medium) }\end{array}$ & $\begin{array}{l}>4.5 \text { meq/100g } \\
\text { (High) }\end{array}$ & Range & Mean \pm SD \\
\hline Forest area & 0 & 100 & 0 & $1.89-3.55$ & $2.55 \pm 0.58$ \\
\hline Industrial area & 100 & 0 & 0 & $0.51-1.45$ & $1.10 \pm 0.33$ \\
\hline Agricultural area & 0 & 66.66 & 33.33 & $3.54-4.66$ & $4.13 \pm 0.45$ \\
\hline
\end{tabular}


in all land use areas. Due to wastewater irrigation, higher organic concentration can adverse effects on soil porosity and make anaerobic environments in the plant root zone.

\section{Effect of wastewater on soil calcium and magnesium}

Exchangeable calcium (meq/100gm) of soil ranged from 2.65-3.35 at clean water irrigated sites in the forest area. Whereas, 3.77-6.80 at wastewater irrigated sites in the industrial area and 3.90-4.65 at wastewater irrigated sites in an agricultural area (Table 3). This indicates the medium status of soil exchangeable calcium in forest and agricultural areas and high in the Industrial area due to the accumulation of calcium deposits through industrial and municipal wastewater irrigation. Soil

Table 4. Descriptive status of macronutrients in Ranipur Rao watershed.

\begin{tabular}{|c|c|c|c|c|c|}
\hline \multicolumn{6}{|l|}{ Nitrogen (N) } \\
\hline \multirow[t]{2}{*}{ Location } & \multicolumn{3}{|c|}{ Percent of samples falling within range } & \multirow[t]{2}{*}{ Range } & \multirow[t]{2}{*}{ Mean \pm SD } \\
\hline & $\begin{array}{l}<280 \mathrm{Kg} \text { / } \\
\mathrm{Ha}(\mathrm{Low})\end{array}$ & $\begin{array}{l}280-560 \mathrm{Kg} / \mathrm{Ha} \\
\text { (Medium) }\end{array}$ & $\begin{array}{l}>560 \mathrm{Kg} / \mathrm{Ha} \\
\text { (High) }\end{array}$ & & \\
\hline Forest area & 0 & 66.66 & 33.33 & $281.2-573.88$ & $429.2 \pm 41.9$ \\
\hline Industrial area & 100 & 0 & 0 & $110.14-70.15$ & $193.8 \pm 68.86$ \\
\hline Agricultural area & 0 & 83.33 & 16.66 & $282.3-582.96$ & $267.4 \pm 39.4$ \\
\hline \multicolumn{6}{|l|}{ Phosphorus $\left(\mathrm{P}_{2} \mathrm{O}_{5}\right)$} \\
\hline Location & $\begin{array}{l}<10 \mathrm{Kg} / \mathrm{Ha} \\
\text { (Low) }\end{array}$ & $\begin{array}{l}\text { 10-25 Kg } \\
\text { (Medium) }\end{array}$ & $\begin{array}{l}>25 \mathrm{Kg} / \mathrm{Ha} \\
\text { (High) }\end{array}$ & Range & Mean \pm SD \\
\hline Forest area & 0 & 100 & 0 & $13.76-22.39$ & $17.91 \pm 3.37$ \\
\hline Industrial area & 33.33 & 66.66 & 0 & $8.96-13.74$ & $10.25 \pm 2.01$ \\
\hline Agricultural area & 0 & 100 & 0 & $17.85-22.23$ & $19.8 \pm 1.69$ \\
\hline \multicolumn{6}{|l|}{ Potassium $\left(\mathrm{K}_{2} \mathrm{O}\right)$} \\
\hline Location & $\begin{array}{l}<110 \mathrm{Kg} / \\
\mathrm{Ha}(\mathrm{Low})\end{array}$ & $\begin{array}{l}110-280 \mathrm{Kg} / \mathrm{Ha} \\
\text { (Medium) }\end{array}$ & $\begin{array}{l}>280 \mathrm{Kg} / \mathrm{Ha} \\
\text { (High) }\end{array}$ & Range & Mean \pm SD \\
\hline Forest area & 0 & 100 & 0 & $119.65-152.32$ & $134.1 \pm 14.07$ \\
\hline Industrial area & 100 & 0 & 0 & $78.32-95.14$ & $86.81 \pm 6.67$ \\
\hline Agricultural area & 0 & 100 & 0 & $125.32-168.65$ & $140.7 \pm 17.36$ \\
\hline \multicolumn{6}{|c|}{ Available sulphur (S) } \\
\hline Location & $\begin{array}{l}<10 \mathrm{ppm} \\
\text { (Low) }\end{array}$ & $\begin{array}{l}\text { 10-30 ppm } \\
\text { (Medium) }\end{array}$ & $\begin{array}{l}>30 \text { ppm } \\
\text { (High) }\end{array}$ & Range & Mean \pm SD \\
\hline Forest area & 0 & 100 & 0 & $11.89-19.88$ & $14.56 \pm 3.32$ \\
\hline Industrial area & 0 & 0 & 100 & $53.14-75.88$ & $62.83 \pm 7.77$ \\
\hline Agricultural area & 0 & 0 & 100 & $31.71-42.88$ & $37.63 \pm 4.27$ \\
\hline
\end{tabular}


exchangeable magnesium (meq/100gm) of soil ranged from 1.89-3.55 at clean water irrigated sites in the forest area. Whereas, 0.51-1.45 at wastewater irrigated sites in the industrial area and 3.54-4.66 at wastewater irrigated sites in an agricultural area. This indicates the medium status of soil exchangeable magnesium in forest and agricultural areas and low in the Industrial area. Notably, wastewater irrigation alters the cation concentration in the soil which affects the nutrient and metal stability among solid and liquid phases of the soil system (Khalid et al., 2017b). However, the effect depends on the absorption of these cations in the applied wastewater (Table 5).

\section{Effect of wastewater on soil macronutrient elements}

$\mathrm{AN}, \mathrm{AP}, \mathrm{AK}$, and AS are essential nutrients for plant growth. The contents of these elements were analyzed and were shown in Table 3. The content of AN in the soil of agricultural wastewater irrigated area indicates high status as compared to industrial and forest areas (Table 4-6). In wastewater irrigated soils, organic nitrogen is transformed into nitrates by soil microorganisms to a greater extent than that

Table 5. Descriptive status of available micronutrients in Ranipur rao watershed.

\begin{tabular}{|c|c|c|c|c|c|}
\hline \multicolumn{6}{|l|}{ Zinc (Zn) } \\
\hline \multirow[b]{2}{*}{ Location } & \multicolumn{3}{|c|}{ Percent of samples falling within range } & \multirow{2}{*}{$\begin{array}{l}\text { Range } \\
\text { Range }\end{array}$} & \multirow{2}{*}{$\begin{array}{l}\text { Mean } \pm \text { SD } \\
\text { Mean } \pm \text { SD }\end{array}$} \\
\hline & $\begin{array}{l}<0.6 \mathrm{ppm} \\
\text { (Low) }\end{array}$ & $\begin{array}{l}0.6-1.0 \mathrm{ppm} \\
\text { (Medium) }\end{array}$ & $\begin{array}{l}>1.0 \text { ppm } \\
\text { (High) }\end{array}$ & & \\
\hline Forest area & 16.7 & 83.33 & 0 & $0.54-0.988$ & $0.77 \pm 0.17$ \\
\hline Industrial area & 16.7 & 50 & 33.33 & $0.50-1.54$ & $0.91 \pm 0.35$ \\
\hline Agricultural area & 33.33 & 33.33 & 33.33 & $0.47-1.25$ & $0.86 \pm 0.30$ \\
\hline \multicolumn{6}{|l|}{ Manganese (Mn) } \\
\hline Location & $\begin{array}{l}<0.07 \mathrm{ppm} \\
\text { (Low) }\end{array}$ & $\begin{array}{l}0.7-0.2 \mathrm{ppm} \\
\text { (Medium) }\end{array}$ & $\begin{array}{l}>0.2 \mathrm{ppm} \\
\text { (High) }\end{array}$ & Range & Mean \pm SD \\
\hline Forest area & 66.66 & 33.33 & 0 & $0.06-0.11$ & $0.07 \pm 0.59$ \\
\hline Industrial area & 50 & 33.33 & 16.7 & $0.05-0.23$ & $0.18 \pm 0.83$ \\
\hline Agricultural area & 0 & 66.66 & 33.33 & $0.09-0.22$ & $0.16 \pm 0.44$ \\
\hline \multicolumn{6}{|l|}{ Iron $(\mathrm{Fe})$} \\
\hline Location & $\begin{array}{l}<4.5 \mathrm{ppm} \\
\text { (Low) }\end{array}$ & $\begin{array}{l}\text { 4.5-5.5 ppm } \\
\text { (Medium) }\end{array}$ & $\begin{array}{l}>5.5 \mathrm{ppm} \\
\text { (High) }\end{array}$ & Range & Mean \pm SD \\
\hline Forest area & 83.33 & 16.7 & 0 & $0.31-0.61$ & $0.44 \pm 0.10$ \\
\hline Industrial area & 50 & 16.7 & 33.33 & $4.26-5.86$ & $4.49 \pm 1.18$ \\
\hline Agricultural area & 16.7 & 50 & 33.33 & $4.19-5.89$ & $4.94 \pm 0.65$ \\
\hline \multicolumn{6}{|l|}{ Copper $(\mathrm{Cu})$} \\
\hline Location & $\begin{array}{l}<0.07 \mathrm{ppm} \\
\text { (Low) }\end{array}$ & $\begin{array}{l}0.7-0.2 \mathrm{ppm} \\
\text { (Medium) }\end{array}$ & $\begin{array}{l}>0.2 \mathrm{ppm} \\
\text { (High) }\end{array}$ & Range & Mean \pm SD \\
\hline Forest area & 16.7 & 83.33 & 0 & $0.02-0.20$ & $0.08 \pm 0.03$ \\
\hline Industrial area & 0 & 66.66 & 33.33 & $0.14-0.23$ & $0.17 \pm 0.02$ \\
\hline Agricultural area & 16.7 & 83.33 & 0 & $0.05-0.19$ & $0.15 \pm 0.17$ \\
\hline
\end{tabular}


observed in non-irrigated agricultural soils (Ramirez et al., 2002). This indicates the high status of AP in forest areas as compared to wastewater irrigated sites. AK was higher in agricultural areas as compared to the forest and industrial areas. AS indicates the high status in industrial areas due to the accumulation of sulphate deposits through various industrial plants. Industrial and domestic wastes of the industrial area (SIDCUL and BHEL) are discharged into the seasonal river Ranipur Rao, Haridwar that leads to the change in nutrient status of soil in the adjoining areas (Kamboj et al., 2013).

This indicates that wastewater irrigation will be of benefit to soils in elevating some of the nutrient elements. Forest planting, especially the use of wastewater for irrigation, can effectively elevate soil nutrient contents, improving soil fertility (Peiyue et al., 2014).

Table 6. Nutrient indices of major and micro nutrients in soils of Ranipur Rao watershed.

\begin{tabular}{|c|c|c|c|c|c|c|c|}
\hline \multirow[t]{2}{*}{ Parameters } & \multirow[t]{2}{*}{ Units } & \multicolumn{2}{|c|}{ Forest area } & \multicolumn{2}{|c|}{ Industrial area } & \multicolumn{2}{|c|}{ Agricultural area } \\
\hline & & $\begin{array}{l}\text { Nutrient } \\
\text { index }\end{array}$ & $\begin{array}{l}\text { Fertility } \\
\text { rating }\end{array}$ & $\begin{array}{l}\text { Nutrient } \\
\text { index }\end{array}$ & $\begin{array}{l}\text { Fertility } \\
\text { rating }\end{array}$ & $\begin{array}{l}\text { Nutri- } \\
\text { ent } \\
\text { index }\end{array}$ & $\begin{array}{l}\text { Fertility } \\
\text { rating }\end{array}$ \\
\hline $\mathrm{pH}$ & & 1.0 & Low & 1.66 & Low & 2.0 & Medium \\
\hline $\begin{array}{l}\text { Electrical } \\
\text { conductivity }\end{array}$ & $\mathrm{ds} / \mathrm{m}^{-1}$ & 2.0 & Medium & 2.0 & Medium & 2.0 & Medium \\
\hline Organic carbon & $\%$ & 2.33 & Medium & 1.83 & Medium & 2.0 & Medium \\
\hline Available nitrogen & $\mathrm{Kg} / \mathrm{ha}$ & 2.33 & Medium & 1.0 & Low & 2.16 & Medium \\
\hline Available phosphorus & $\mathrm{Kg} / \mathrm{ha}$ & 2.0 & Medium & 1.33 & Low & 2.0 & Medium \\
\hline Available potassium & $\mathrm{Kg} / \mathrm{ha}$ & 2.0 & Medium & 1.0 & Low & 2.0 & Medium \\
\hline Available calcium & $\begin{array}{l}\mathrm{meq} / 100 \\
\mathrm{~g}\end{array}$ & 2.0 & Medium & 2.66 & High & 2.16 & Medium \\
\hline Available magnesium & $\begin{array}{l}\mathrm{meq} / 100 \\
\mathrm{~g}\end{array}$ & 2.0 & Medium & 1.0 & Low & 2.34 & Medium \\
\hline Available sulphate & ppm & 2.0 & Medium & 3.0 & High & 3.0 & High \\
\hline Available zinc & ppm & 1.83 & Medium & 1.0 & Low & 1.83 & Medium \\
\hline Available iron & ppm & 2.16 & Medium & 1.0 & Low & 2.16 & High \\
\hline Available manganese & ppm & 1.33 & Low & 2.30 & Medium & 2.37 & High \\
\hline Available copper & ppm & 1.0 & Low & 2.37 & High & 2.22 & medium \\
\hline
\end{tabular}




\section{Effect of wastewater on soil micronutrient elements}

Zinc is essential in plants for several biochemical processes such as cytochrome and nucleotide synthesis, auxin metabolism, chlorophyll production, enzyme activation, and the maintenance of membrane integrity (Halvin et al., 2010). The available zinc content was highest in the industrial area i.e. $1.54 \mathrm{mg} / \mathrm{kg}$. The available manganese content was highest in the industrial area i.e. $0.23 \mathrm{mg} / \mathrm{kg}$ i.e. slightly high from safe limits. Iron is a vital micronutrient for almost all living beings. It plays an important role in metabolic processes like DNA synthesis, respiration process, and photosynthesis processes (Raut and Sahoo, 2015). The available iron content was highest in the agricultural area i.e. $5.89 \mathrm{mg} / \mathrm{kg}$. Copper is also an important micronutrient, required for lignin synthesis and acts as a constituent of ascorbic acid, oxidase, phenolase, and plastocyanin in plants (Halvin et al., 2010). The available copper content was highest in the industrial area i.e. $0.23 \mathrm{mg} / \mathrm{kg}$. The nutrient index indicates the high status of $\mathrm{Cu}$ in the industrial area, it creates several defects in the human system. The low status of $\mathrm{Cu}, \mathrm{Mn}$, and medium status of $\mathrm{Zn}$ and iron was found in the clean water irrigated forest area. In the agricultural area, $\mathrm{Zn}$ indicates medium status. $\mathrm{Fe}, \mathrm{Cu}$, and $\mathrm{Mn}$ indicate the high status due to wastewater irrigation and recommended fertilizer applied. Long-term irrigation with raw effluents causes amassing of high concentration of heavy metals in soil and therefore in crop plants (particularly leafy vegetables), which can be phytotoxic to crop plants and wellbeing risk to animals and humans.

\section{Conclusion}

The results of the current study concluded that long-term application of wastewater in Ranipur Rao Shivalik hill watershed areas, nutrients, and total organic matter increasing in the soils; but there is anxiety related to soil EC increment and the accumulation of possibly toxic elements, like $\mathrm{Pb}, \mathrm{Cu}$, and Ni. To avoid unnecessary destructive impacts from the wastewater applied to the soil, regular evaluation of soil quality in such regions is essential. Furthermore, remediation techniques along with management strategy are needed in the study area which is considering a key point for soil quality improvement.

Conflict of interest: Authors declare that they have no conflict of interest.

\section{Acknowledgments}

This research work was financially supported by the University Grants Commission (UGC), New Delhi, India, [RGNF: 201718-RGNF-2017-18-SC-UTT-30512] to Ms. Manisha Bharti. And also highly thankful to the Department of Zoology and Environmental Sciences, Gurukula Kangri (Deemed to be University), Haridwar for providing necessary facilities during my research work. 


\section{References}

Abedikoopayee, J., Afyoni, M., Mousavi, S. F., Mostafazadeh, M.B. and Bagheri, M. (2003). The effect of sprinkler irrigation and surface treated wastewater on soil salinity. Water and Wastewater Magazine, 45: 2-12.

Akpoveta, O.V., Osakwe, S.A., Okoh, B.E. and Otuya, B.O. (2010). Physicochemical Characteristics and levels of some heavy metals in soil around metal scarp dumps in some parts of delta state, Nigeria. Journal of Applied Science and Environmental Management, 14 (4): 57-60.

Alikhales, D. and Smalzadeh S. M. (2010). The effect of irrigation with the treated wastewater Zinc private cotton plant. Iranian Journal of Soil and Water Research, 2: 225-232.

AmaraDenis (2016). International Journal of Food, Agriculture and Veterinary Sciences ISSN: 2277-209X (Online) An Open Access, http://www.cibtech.org/jfav.htm, 6(3) September-December, pp. 1-15.

Anderson, J.M. and Ingram, J.S.I. (1993). Tropical Soil Biology and Fertility: A Handbook of Methods. CAB International, pp. 30-52.

Andreas, P. and Berndt-Micheal, W. (2005). Soil sampling and storage. In: Margesin R, Schinner F, editors. Manual for soil analysis monitoring and assessing soil bioremediation, Springer-Verlag: Berlin Heidelberg: pp. 3-13.

Arit, E. (2016). Soil Nutrients, https://permaculturenews.org/2016/09/07/soil-nutrients/.

Behera, P.K. (2014): Soil and solid waste analysis. A laboratory Manual, Dominant Publishers and Distributors Pvt Ltd, New Delhi, India, pp. 1-85.

Bharti, M. and Kamboj, N. (2018). Impact of different land uses on soil characteristics in Ranipur Rao watershed in Haridwar district, Uttarakhand. International Journal of Creative Research Thoughts, 6 (1): 1147-1154.

Bharti, M. and Kamboj, N. (2020). Occurrence and diversity of mycofloral population in soil of two different land use types in Haridwar region (Uttarakhand), India. Journal of Advance Scientific Research, 11(1): 208-214.

Brajendra, A., Latha, P.C., Surekha, K., Prasad Babu, M.B.B., Ghosh, T.J. and Bhadana, V.B. (2014). Soil Health Testing Manual. Parmar Publishers and Distributors, India.

Eswaran, H., Lal, R. and Reich, P. (2001). Land degradation an overview: In response to land degradation, E.M. Bridges, et al., Eds. Enfield, NH, USA: Science publisher, pp. 20-35.

Havlin, H.L., Beaton, J.D. and Tisdale, S.L. (2010). Soil Fertility and Fertilizers- an introduction to nutrient management. 7th ed. India: PHI Learning Private Limited; 2010.

Hussain, I., Raschid-Sally, L., Hanjra, M.A., Marikar F. and van der Hoek W. (2002). Wastewater Use in Agriculture: Review of Impacts and Methodological Issues in Valuing Impacts. Colombo, International Water Management Institute, IWMI.

Jackson, M.L. (1958). Soil chemical analysis. Prentice - Hall of India Private Limited. New Delhi.

Johnson, D.L., Ambrose, S.H., Bassett, T.J., Bowen, M.L., Crummey, D.E., Isaacson, J. S., Johnson, D.N., Lamb, P., Saul, M. and Winter-Nelson, A.E. (1997). Meanings of Environmental Terms. Journal of Environment Quality, 26 (3): 581. https://doi.org/10.2134/jeq1997.00472425002600030002x.

Juan, C., Durán-Álvarez, J.C. and Jiménez-Cisneros, B. (2014). Beneficial and Negative Impacts on Soil by the Reuse of Treated/Untreated Municipal Wastewater for Agricultural Irrigation - A Review of the Current Knowledge and Future Perspectives, Environmental Risk Assessment of Soil Contamination, Maria C. Hernandez-Soriano, IntechOpen, https://doi.org/10.5772/57226.

Kamboj, N. (2013). Physico-chemical parameters of industrial and domestic waste at SIDCUL area, Haridwar (Uttarakhand). Journal of Sustainable Environmental Research, 2(1): 125-131.

Karimzadeh, M., Alizadeh, A., Ariamohammadi, M. (2012). The effects of wastewater irrigation on soil saturated hydraulic conductivity. Soil and Water Journal, 26: 47-53.

Kavitha, C. and Sujatha, M.P. (2015). Evaluation of soil fertility status in various agro ecosystems of Thrissur District, Kerala, India. International Journal of Agricultural Crop Science, 8: 328-338. 
Khai, N.M. Öborn, I., Hillier, S. and Gustafsson, J.P. (2008). Modeling of metal binding in tropical Fluvisols and Acrisols treated with biosolids and wastewater. Chemosphere, 70: 1338-1346.

Khalid, S., Shahid, M., Bibi, I., Sarwar, T., Shah, A.H. and Niazi, N.K. (2018). A Review of Environmental Contamination and Health Risk Assessment of Wastewater Use for Crop Irrigation with a Focus on Low and High-Income Countries. International Journal of Environmental Research and Public Health, 15(5): 895. https://doi.org/10.3390/ijerph15050895

Khalid, S., Shahid, M., Dumat, C., Niazi, N.K., Bibi, I., Gul Bakhat, H.F.S., Abbas, G., Murtaza, B. and Javeed, H.M.R. (2017). Influence of groundwater and wastewater irrigation on lead accumulation in soil and vegetables: Implications for health risk assessment and phytoremediation. International Journal of Phytoremediation, 19: 1037-1046.

Kretschmer, N., Ribbe, L. and Gaese, H. (2002). Wastewater Reuse for Agriculture. Technology Resource Management and Development. Water Management, 2(1): 35-61.

Kumar, V., Kumar, S., Srivastava, S., Singh, J. and Kumar, P. (2018). Water quality of River Ganga with reference to physico-chemical and microbiological characteristics during Kanwar Mela 2017, at Haridwar, India: A case study. Archives of Agriculture and Environmental Science, 3(1): 58-63.

Kumar, V., Kumar, P., Singh, J. and Kumar, P. (2020). Current status of water pollution by integrated industrial hubs (IIHs) in India. Environmental Degradation: Causes and Remediation Strategies, Volume 1, pp. 104.

Lone, P.A., Bhardwaj, A.K., Shah, K.W. and Bahar, F.A. (2016). Assessment of Soil Macronutrient Status of Some Threatened Medicinal Plants of Kashmir, India. Research Journal of Botany, 11: 18-24.

Mohsen, I. and Ali, S.T. (2017). The effect of municipal wastewater on soil chemical properties. Solid Earth Discuss, 6(1): 1-14. https://doi.org/10.5194/se-2017-6.

Parker, F.W., Nelson, W.L., Winters, E. and Miles, J.E. (1951). The broad interpretation and application of soil test summaries. Agronomy Journal, 43(3): 103-112 (1951).

Peiyue, li., Jianhua Wu. And H. Qian., (2014). Effects of Irrigation with Paper Wastewater on Soil Fertility. Conference Paper January 2014, https://doi.org/10.13140/2.1.4661.3124.

Ramesh, V., Balloli, S.S., Sharma, K.L., Ramachandran, K., Korwar, G.R. and Ramakrishna, Y.S. (2008). Characterization of Soil for Physical Properties under Different Land Use Systems. Indian Journal of Dryland Agricultural Research and Development, 23(1): 102-109.

Ramírez-Fuentes, E., Lucho-Constantino, C., Escamilla-Silva, E. and Dendooven, L. (2001). Characteristics and Carbon and Nitrogen Dynamics in Soil Irrigated with Wastewater for Different Lengths of Time. Bioresource Technology, 85(2): 179-187.

Rehman, O., Ahmad, B. and Afzal, S. (2010). Soil fertility and salinity status of Attock district. Journal of Agriculture Research, 48(4): 505-516.

Roser, M., Ritchie, H. and Ortiz-Ospina, E.(2013). "World Population Growth". Published online at OurWorldInData.org. Retrieved from: 'https://ourworldindata.org/world-population-growth' [Online Resource].

Rout, G.R. and Sahoo, S. (2015). Role of iron in plant growth and metabolism. Reviews in Agricultural Science, 3: 1-24.

Smith, J.L. and Doran, J.W. (19960. Measurement and use of $\mathrm{pH}$ and electrical conductivity for soil quality analysis, Soil, 49: 1-9.

Tilley, E., Ulrich, L., Lüthi, C., Reymond, Ph. and Zurbrügg, C. (2014). Compendium of Sanitation Systems and Technologies (2nd Revised Edition). Swiss Federal Institute of Aquatic Science and Technology (Eawag), Duebendorf, Switzerland, pp. 175. ISBN 978-3-906484-57-0. Archived from the original on 8 April 2016.

Trivedy, R.K. and Goel, P.K. (1998). In: Chemical and Biological Methods for Water pollution studies. Environmental Publication, Carad, India, pp. 1-10.

Vaseghi, S., Afyouni, M., Shariat Madari, H. and Mobli, M. (2005). Effect of sewage sludge on same macronutrients concentration and soil chemical properties. Journal of Water and Wastewater, 53: 18-25. 
World Health Organization (1989), WHO. Health Guidelines for the Use of Wastewater and Excreta in Agriculture. Geneve.

$* * * * *$

Cite this chapter as: Bharti, M., Kamboj, N. and Kamboj, V. (2020). Effect of untreated wastewater on soil quality: A case study in Ranipur Rao watershed in Haridwar region (Uttarakhand), India. In: Advances in Environmental Pollution Management: Wastewater Impacts and Treatment Technologies, Volume 1, Eds. Kumar, V., Kamboj, N., Payum, T., Singh, J. and Kumar, P., pp. 145-157, https://doi.org/10.26832/ aesa-2020-aepm-010 